\title{
A Review on Quadratic Boost Topology-Based PFC Techniques
}

\author{
Salman Akram Memon ${ }^{1}$, Abdul Hakeem Memon ${ }^{1}$, Ashfaque Ahmed Hashmani ${ }^{1}$ \\ ${ }^{1}$ Research Student, ME (Electrical Power), IICT, Mehran UET Jamshoro, Pakistan, \\ salmanmemon9541@gmail.com \\ ${ }^{1}$ Assistant Professor (Department of Electrical Engineering),IICT, Mehran UET Jamshoro, Pakistan, \\ hakeem.memon@faculty.muet.edu.pk \\ ${ }^{1}$ Professor (Department of Electrical Engineering), IICT, Mehran UET Jamshoro, Pakistan, \\ ashfaque.hashmani@faculty.muet.edu.pk
}

\begin{abstract}
Electronic devices require DC voltage for their operation so rectification ( $\mathrm{AC}$ to $\mathrm{DC}$ conversion) is needed to convert $\mathrm{AC}$ voltage from the mains to DC. During this conversion, harmonics are generated in the system as well as power factor (PF) gets poor hence degrading power quality. Power factor correction (PFC) converters are being commonly used to increase PF and reduce harmonics. Boost PFC Converter is the mostly used topology for active power factor correction because of several benefits like series input inductor, high PF, but its voltage gain is not that good and it has output voltage ripple. Quadratic Boost PFC Converter can be used to overcome these two drawbacks by providing high voltage gain and less output voltage ripples. This paper represents applications and topologies of Quadratic Boost Converter, latest control techniques to achieve high voltage gain, regulated output and, high PF. Also, comparison is made between Boost Converter and Quadratic Boost PFC Converter. Finally, conclusion is made of this survey.
\end{abstract}

Key words:Quadratic boost, Boost, PFC converter, Harmonics, Voltage gain, Output voltage ripple, PF, Quadratic boost applications, Quadratic boost topologies

\section{INTRODUCTION}

The use of electronic devices is increased with the advancement of technology. Electronics need DC voltage for the operation so $\mathrm{AC}$ to $\mathrm{DC}$ conversion is required. Power electronic converters are used in these devices for conversion purpose. Main application of power electronics includes DCDC converters that are used in industrial, commercial and residential application providing regulated output. Diodes and thyristors used in power electronics converters give controlled and semi controlled DC output. Due to non-linearity of diode and thyristor, there are several problems like distorted currents are drawn from the line when connected to ac mains that result in low PF and high total harmonic distortion (THD). These distorted currents cause several problems such as voltage distortion,heating, noise and power loss [1], [2], [3].So, this harmonic content produced by non-linear elements of electronic devices connected to AC supply system should be in such limit that it meets regulatory standard. Harmonic content can be reduced by active and passive method of power factor correction (PFC), passive method uses passive components with bridge diode circuit whereas active method uses switches like MOSFET and IGBTs. The requirement of meeting regulatory standard is fulfilled by using active PFC circuits that with the help of switching devices shape the line current to be sinusoidal in nature and follow the wave form of line voltage. PFC converters are being commonly used in AC to $\mathrm{DC}$ power conversions to get $\mathrm{PF}$ near to unity and to reduce harmonic distortion so as to meet the standards like IEC61000-3-2 and IEEE 519 [4]. Along with high PF and low THD, there is a need of output voltage with low ripple in PFC converter like in LED lightning driver and programmable output adopter for mobile devices and so on which is not possible by using Boost PFC converter and can be achieved by using Quadratic Boost PFC converter [5]. Power factor (PF) near to unity and good voltage regulation can be obtained by using two stage PFC approach shown in figure 1 [1].

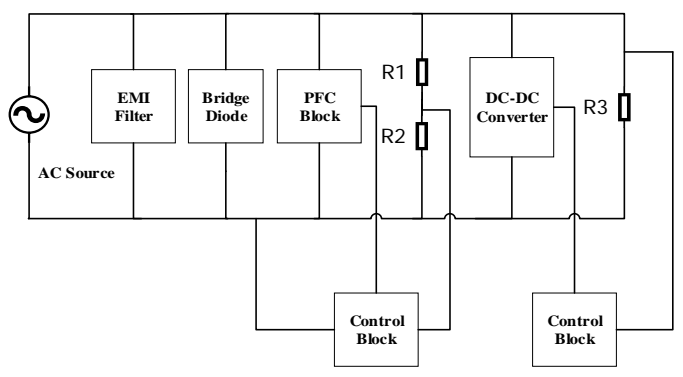

Figure 1: Basic two stage PFC converter circuit

\section{STUDY OBJECTIVES}

This paper aims to present topologies and application of Quadratic Boost PFC converter. Different controlling techniques to improve converter's performance, voltage regulation and power factor presented by many authors have been discussed. Detailed comparison has also been made between Boost and Quadratic Boost PFC Converter.

\section{METHODOLOGY}

\subsection{Comparison between Boost and Quadratic Boost PFC Converter}

The comparison between Boost and Quadratic Boost PFC Converter is discussed here in terms of their input and output characteristics, design construction, voltage gain an defficiency. The input inductor peak current of Quadratic Boost PFC is smaller compared to Boost PFC converter [6]. Boost PFC converter has smooth continuous input current waveform due to series inductor in input side [7] whereas 
Quadratic Boost PFC converter has smoother continuous wave form due to two inductors in input side. The study in [6] also shows that Quadratic Boost PFC converter reduces output voltage ripple, but it has more THD compared to Boost PFC converter. Boost PFC Converter is used for stepup applications due to its simple design and low cost but it is not well suited for highstep-up applications because of low voltage gain. To get high voltage gain from Boost PFC Converter, its power switch should have high duty cycle that results in high conduction losses degrading converter's efficiency. Another simple way to obtain high gain without increasing duty cycle is to cascade boost converter which requires more switches and results in complex design and complex circuit. Using Quadratic Boost PFC converter, high voltage gain can be obtained which is a two-stage boost converter with single switch topology overcoming the disadvantage of conventional Boost PFC Converters [8], [9], [10]. The study in [11] shows Quadratic Boost PFC Converter has more efficiency compared to Boost PFC Converter, because there are high conduction and switching losses as current of each boost stage flows from the single common switch. It is also because Quadratic Boost PFC Converter is made from cascaded connection of two boost converters [5], [9]. The conclusion of this discussion is given in the table 1 .

Table 1: Comparison of boost and quadratic boost PFC parameters

\begin{tabular}{|c|c|c|c|}
\hline Parameters & $\begin{array}{l}\text { Boost PFC } \\
\text { Converter }\end{array}$ & $\begin{array}{l}\text { Quadratic } \\
\text { Boost PFC } \\
\text { Converter }\end{array}$ & Reference \\
\hline Input & $\begin{array}{c}\text { Smoothcontinuous } \\
\text { current waveform, } \\
\text { more input } \\
\text { inductor peak } \\
\text { current, more } \\
\text { THD }\end{array}$ & $\begin{array}{l}\text { Smoother } \\
\text { continuous } \\
\text { current } \\
\text { waveform, } \\
\text { less input } \\
\text { inductor } \\
\text { peak } \\
\text { current, less } \\
\text { THD }\end{array}$ & [6], [7]. \\
\hline Output & $\begin{array}{l}\text { High output } \\
\text { voltage, more } \\
\text { output voltage } \\
\text { ripples }\end{array}$ & $\begin{array}{c}\text { Higher } \\
\text { output } \\
\text { voltage, less } \\
\text { output } \\
\text { voltage } \\
\text { ripples }\end{array}$ & [6], [8]. \\
\hline $\begin{array}{l}\text { Voltage } \\
\text { Gain }\end{array}$ & Low & High & $\begin{array}{ll}{[8],} & {[9],} \\
{[10] .} & \end{array}$ \\
\hline Design & Simple & Complex & $\begin{array}{ll}{[8],} & {[9],} \\
{[10] .} & \end{array}$ \\
\hline Efficiency & High & Low & $\begin{array}{l}\text { [5], [9], } \\
{[11] .}\end{array}$ \\
\hline
\end{tabular}

\section{APPLICATION OF QUADRATIC BOOST CONVERTER (QBC)}

DC-DC converters with high gain have become popular due to their use in solar photovoltaic (PV) system and electric vehicles (EV) [12]. QBC is used for the applications when high voltage gain is required like PFC and PV applications [13]. This section presents literature review of QBC used in application of EV, PV cell and PFC.

\subsection{Photovoltaic (PV) Cell}

Solar PV is the environment friendly technology because it generates electricity with no emission in the atmosphere as well as having very low maintenance cost [14]. PV panel's output is lower than needed by inverter for PV applications therefore this voltage needs to be increased. The requirement of high voltage can be achieved by connecting PV panels in series but with certain limitations such as shadowing effect, efficiency consideration etc. [13]. Boost converter, cascade boost converter, buck-boost converter, sepic converter and cuk, converter are usually used toincrease the voltage gain. However, these converters are not efficient enough to produce high voltage due to switching losses and high ripple in current. Boost and Buck-boost converter can provide high voltage gain with very high duty cycle but it increases component stress as well as causes switching loss [15]. The simplest method to obtain high voltage gain is using QBC [9]. Authors in [10], [15], [16] use QBC in photovoltaic application. In [10] QBC with high voltage gain is presented which can track maximum power point (MPP) from PV module using incremental conductance (IC) algorithm under varying operating conditions. Action of getting maximum power from PV modules is known as maximum power point tracking (MPPT). In [15] QBC with switch capacitor is presented which gives reduced voltage stress and high conversion ratio with same value of duty cycle and input voltage. This converter is then connected after PV panel to charge the battery of $1000 \mathrm{~W}, 48 \mathrm{~V}$. It was found from experimental results that even for the value of low voltage obtained from PV panel converter produce enough charging voltage to the battery. In [16] 100W, QBC with energy storage system is presented for low PV application by using PI controlled technique. It solves the intermitted power problem from output of PV panel by connecting battery in parallel with capacitor of first stage of QBC, the battery gets charged and discharged to maintain constant power at load side. PI controller is used to obtain regulated voltage at output side received from PV panel. Low PV applications are PV power telecommunication system and residential application. Block diagram of PV panel charging the battery is shown in figure 2 in which voltage is boosted with the help of QBC, an inverter can also be connected after battery to converter DC into AC for supplying the electrical loads.

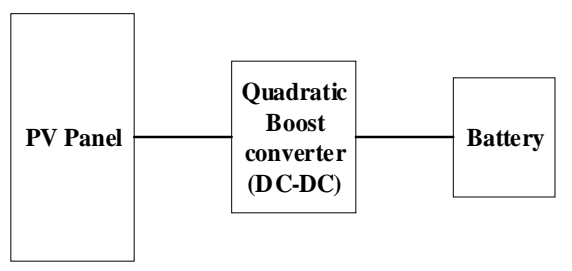

Figure 2: Block diagram for PV panel charging a battery 


\subsection{Electric Vehicle (EV)}

Fuel cell, battery and ultra-capacitors can be used as energy source for Electric Vehicle's propulsion system as shown in figure 3. However, fuel cell (FC) is traditionally used as primary source of energy in electric vehicles, and it provides pollution free and efficient operation compared to vehicles using internal combustion engines which burns diesel and petrol for its propulsion system [17].Fuel cell based Electric Vehicles have two conversion stages; DC-DC and DC-AC. DC-DC conversion can be obtained by using different topologies such as full-bridge, forward, flyback converter that results in high DC voltage and DC-AC converter is obtained by using an inverter [18]. Both of these conversions are shown in figure 3; a QBC is performing DC-DC conversion. The main problem in fuel cell based electric vehicle is that FC produces high current and low voltage. Normally, FC has a voltage of $1.1 \mathrm{~V}$. To obtain high voltage, FC stack is used, formed by connecting FCs in series however it increases cost as well as vehicle's weight. For fuel-cell based vehicles high voltage gain is needed, conventionally used boost converter cannot provide high gain due to losses related with inductor, capacitor and diode degrading converter's efficiency. Cascaded boost converter also gives high gain but results in complex converter design and more switches leading to more losses. Interleaved boost converter used with FC draws current no ripple but it has limited voltage gain. Multi-level DC-DC converters are capable of providing high voltage gain but having problems like complex structure and large size for EV application [19], [20]. QBC provides high voltage gain with tradeoff between efficiency and operation range of duty cycle compared to other topologies [21]. Authors in [17], [22], [23] use QBC with fuel cell in electrical vehicle application. In, [17] QBC with sliding mode-controlled technique is used to boost the output voltage of fuel cell and the result shows that this controller provides regulated voltage at DC link during changing load condition as needed by automobile application. In [22] QBC is presented for fueln tistlt applications with no current and voltage stress on switch with high efficiency. In [23] interleaved QBC is designed for application of fuel cell and coupled inductor is used to improve converter's performance and efficiency.

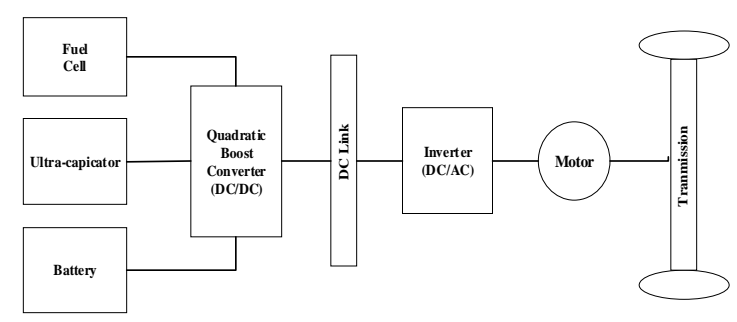

Figure 3: Architecture of Electric Vehicle (EV)

\subsection{Power Quality Improvement}

Along with producing high output voltage, another usage of QBC is power factor correction (PFC) circuit. This converter has series inductor at input due to which it is suitable for power factor correction applications. The converter can be designed to be operated in four modes: CCM-CCM,CCMDCM, DCM-CCM and DCM-DCM. For low power applications, converter is operated in discontinuous conduction mode (DCM) whereas for high power applications it is operated in continuous conduction mode (CCM). Among these modes, In DCM, the converter can automatically be operated as power factor correction circuit because it works as natural current shaper when being operated in DCM mode and no control loop is required but required in case of CCM [24], [5] It is also mentioned in [25] DC-DC converters when being operated in DCM have the ability of self- power factor correction because inductor's peak current samples the line voltage automatically. In addition to self-power factor correction, DCM has better features: constant frequency switching (beneficial for inductor design and EMI filter), zero current turning off on switch, and no reverse recovery of diode compared to CCM in which diode suffers from reverse recovery and has hard switching. However, in CCM inductor ripple current is very small that results in low RMS current on inductor and switch leading to high efficiency [26], [27]. Inductor's current when QBC is operated in DCM is shown in figure 4.

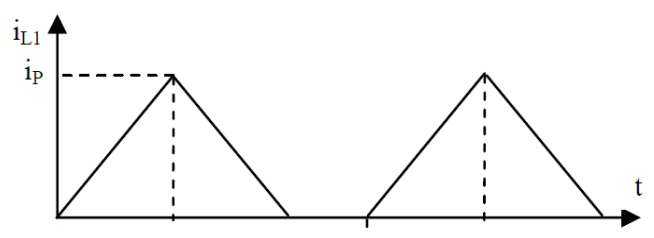

Figure 4: Inductor's current in DCM [24]

\section{ANALYSIS}

\subsection{Quadratic Boost PFC Converter Topologies}

\subsubsection{Conventional Quadratic Boost PFC Converter}

pology, control action is obtained by connecting the switch after second inductor as shown in figure 5. Different control techniques are used [5], [28], [29] to improve its input PF and load and line voltage regulation.

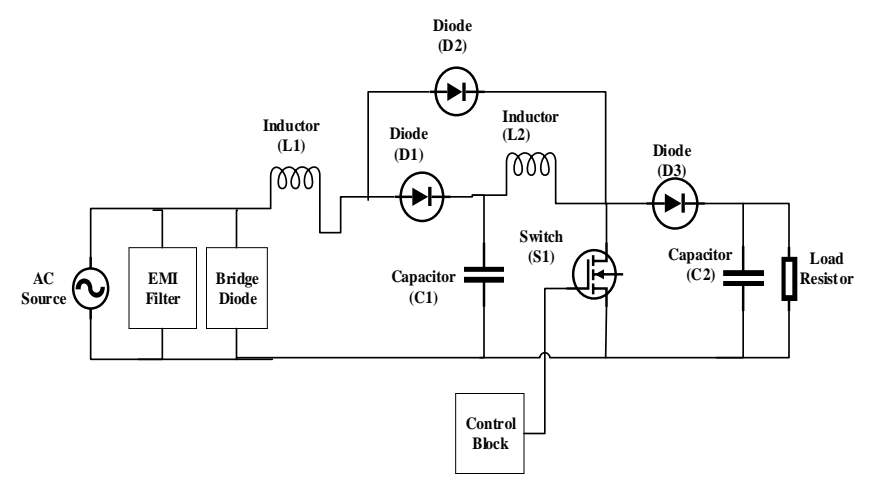

Figure 5: Conventional Quadratic Boost PFC topology

The study in [4] uses $100-240 \mathrm{~V}, 100 \mathrm{~W}$ prototype being operated in DCM-DCM and variable duty cycle control (VDC) technique is used to improve converter's PF which is not good when duty cycle is constant. When duty cycle is constant, the PF is 0.9837 and 0.9249 for voltages $110 \mathrm{~V}$ and $220 \mathrm{~V}$ respectively. The PF is improved to 0.9975 and 0.9905 
for voltages $110 \mathrm{~V}$ and $220 \mathrm{~V}$ respectively when duty cycle is variable. In this paper [28] $100 \mathrm{~W}$ prototype is used with proportional integral derivative (PID) controller and fractional order proportional integral derivative (FOPID) controller for load and line variation. It was found that, load and line variation conditions give better steady state response but it has poor dynamic response with integer order PID controller where as FOPID controller's response during line and load fluctuations is better and it also give better transient and steady state responses. The authors in [29] use sliding mode controlled-technique for $100 \mathrm{~W}$ prototype that gives quick regulated output voltage for both line and load regulation. It was also found that for line regulations sliding mode controller gives required value of output voltage quickly compared to PID controller with no overshooting. The experimental results show that in case of line regulation when input voltage is changed from $9.8 \mathrm{~V}$ to $18.2 \mathrm{~V}$ the output comes to a desired voltage of $79 \mathrm{~V}$ within $2.25 \mathrm{~s}$ and $7.5 \mathrm{~s}$ respectively for both voltages. For load variation of $56.5 \mathrm{ohm}$ and $69.278 \mathrm{ohm}$, the value of output voltage comes to $79 \mathrm{~V}$ within $4.5 \mathrm{~s}$ and $4.4 \mathrm{~s}$ respectively. In this paper [9] $300 \mathrm{~V}$ $120 \mathrm{~W}$ prototype is used with high voltage gain by using coupled inductor and reduced voltage stress by using clamping circuits. Reduced voltage stresses don't allow additional power losses to occur that increases converter's efficiency. The authors in [30] analyze the operation of quadratic boost converter by using prototype of 12-48 V, $100 \mathrm{~W}$ and it was observed based on experimental results that converter operates well enough throughout the range of its operation and gives highest efficiency of $83 \%$.

\subsubsection{Interleaved Quadratic Boost PFC Converter}

This topology consists of switches, diodes and inductors connected in parallel resulting in parallel connected quadratic boost converter as shown in figure 6 . Interleaving of converters make them suitable for high power applications and results in better efficiency, fast switching, and output voltage with less ripple and reduced inductor current ripple allowing use of small size filters [23], [31], [32].

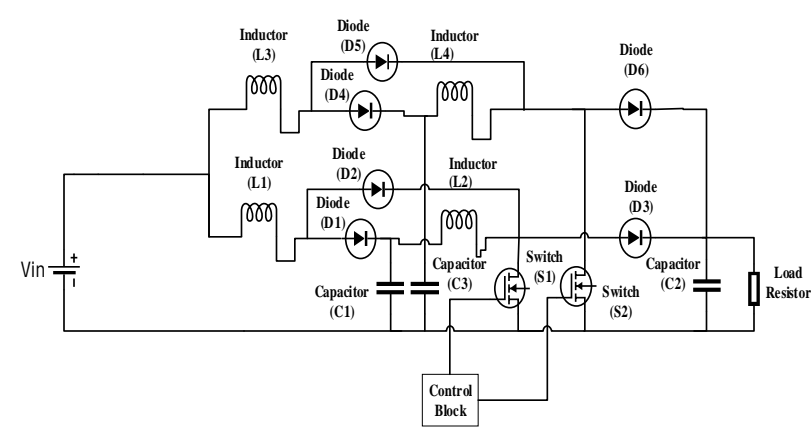

Figure 6: Interleaved Quadratic Boost PFC topology

Authors in [23] use 40-57V, $2.5 \mathrm{~kW}$ prototype for fuel cell applications and examined it for different structures of inductor, also the input of 40-57 (common in FC stacks) has been boosted to $400 \mathrm{~V}$ using proposed converter. Further, their designed coupled inductor improves converter's efficiency and performance. Authors in [33] use 18-380 V, $150 \mathrm{~W}$ prototype in which voltage-lift capacitor technique is used that not only doubles the gain of this topology but also reduces switches voltage stresses to $18.95 \%$ of the output voltage. Also, switches have been operated with duty ratio of 0.5 and $180^{\circ}$ phase shift that nullify source current ripple. Furthermore, the proposed converter gives efficiency of $94.7 \%$ at full load. The authors in [34] present $24 \mathrm{~V}$ to $38 \mathrm{~V}, 100 \mathrm{~W}$ prototype whose gain is increased using voltage lift technique. Also, its input inductor current ripple content is reduced to $9.66 \%$ to the total current magnitude due to interleaving technique. The proposed converter in full load operating condition gives efficiency of $92.5 \%$. They also conclude that input current with no ripple and high voltage gain make this converter suitable for PV applications.

\subsubsection{Non-isolated Quadratic Boost PFC Converter}

In this topology, the term "Non-isolated" means a converter with no transformer. Non-isolated converters are light in weight and have low cost because of absence of transformer. Since no transformer is used to increase the voltage gain, there is a limitation of high voltage gain. Such type of topology finds its application in dc microgrid where isolation is not required and is well suited for low to medium power application [12] [35]. Authors in [12], [36], [38], [39] present different circuit configurations of non-isolated QBC to increase the voltage gain. Circuit configuration of [12] that uses switched capacitor and inductor to make new voltage boost cell is shown in figure 7 .

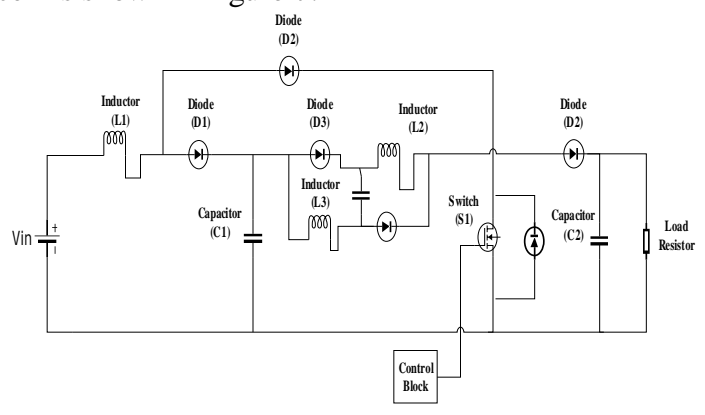

Figure 7: Non-isolated Quadratic Boost PFC Topology [12]

Authors in [12] present $100 \mathrm{~W}$ prototype which gives twice gain compared to conventional QBC by using simple circuit configuration with one switch. It was found that converter gives efficiency of $88 \%$. In [36], $75 \mathrm{~W}$ prototype is presented that gives high voltage gain compared to conventional QBC by adding capacitor, inductor and diode. Capacitor and diode also reduce voltage stresses on main switch. The simulation results also show that properly designed current and voltage give good results for converter's dynamic condition. In [37], prototype of bidirectional QBC (can be used as quadratic boost and buck converter) is presented with four switches which are magnetically coupled to provide wide range conversion ratio. The proposed converter uses magnetic coupling of two inductor and a damping network which eliminate right half plan (RHP) zero problems and makes it capable of handling large ripple current in quadratic buck mode. Its bidirectional nature allows it to use in the application of battery charging, UPS, hybrid EV etc. In [38], authors analyze the performance of transformerless (nonisolated) single switch QBC with high voltage gain for photovoltaic system connected to grid. A detailed simulation and hardware analysis is done with MPPT for verifying 
converter's usage in PV application. In [39], 12V 40Wprototype is presented by combing QBC with voltage multiplier cell which provides high voltage gain, high efficiency of $88 \%$ and low stress on semiconductor devices. The proposed converter's construction is simple with single switch.

\section{CONCLUSION}

Harmonics generated during AC to DC conversion should be within limits set by IEEE and IEC and to meet these standards, passive PFC is not well enough. Active PFC using Boost PFC converter can reduce harmonics and provide high $\mathrm{PF}$ but it has drawback of ripples at output which can be overcome by using Quadratic Boost PFC converter. This paper literature review concludes that for high power applications along with improved power factor, there is a need of high voltage gain and using Boost PFC Converter with high duty cycle results in switching and conduction losses degrading converter's efficiency so Quadratic Boost PFC converter is well suited option. This study also shows that among all operating modes: CCM-CCM, CCM-DCM, DCM-CCM and DCM-DCM, Quadratic Boost Converter operating in DCM has the ability of self-power factor correction but with drawback of low efficiency due to current ripple. Controlling schemes i.e., PID, FOPID, Sliding Mode provide voltage regulation during line and load variations. Other controlling schemes like Variable duty cycle (VDC) results in high PF.Application of QBC in photovoltaic panel and electric vehicle fulfils the requirement of high output voltage. It is also concluded from the literature review that traditional and non-isolated (transformerless) topology is suitable for medium power application whereas interleaved topology is well suited for high power applications.

\section{REFERENCES}

[1] M. J. A. C. M. R. P. P. A. a. J. U. Oscar García, "Single Phase Power Factor Correction: A Survey,"IEEE TRANSACTIONS ON POWER ELECTRONICS, VOL. 18, NO. 3, vol. 18, no. 3, pp. 749-755, May 2003.

[2] I. B. G. Z. a. P. K. Huai Wei, "A Single-Switch ACDC Converter with Power,"IEEE TRANSACTIONS ON POWER ELECTRONICS, VOL. 15, NO. 3,, pp. 421-430, May, 2000.

[3] A. G. a. Dhanya.B.Nair, "Simulation of fault tolerant operation of boost converter during open and short circuit switch failure,"International Journal of Emerging Trends in Engineering Research, vol. 3, no. 9, pp. 109-115, 2015.

[4] E. E. E.-K. S. a. S. H.Z.Azazi, "Review of Passive and Active Circuits for Power Factor Correction in Single Phase, Low Power AC-DC Converters," in Proceedings of the 14th International Middle East Power Systems Conference (MEPCON'10), Cairo University, Egypt, December 2010.
[5] P. Y. G. Z. J. X. a. Z. C. Zhengge Chen, "Variable Duty Cycle Control for Quadratic Boost PFC Converter," IEEE TRANSCTIONS ON INDUSTRIAL ELECTRONICS, 2016.

[6] J. X. Z. D. L. S. a. P. Y. Tiesheng Yan, "Quadratic Boost PFC Converter with Fast Dynamic Response and Low Output Voltage Ripple,"IEEE , pp. $402-$ 406, 2013.

[7] S. Abdel-Rahman, "CCM PFC boost converter design,"Infineon, Tech. Rep. DN 2013-01, 2013.

[8] K. .. a. A. Benny, "Analysis and Implementation of Quadratic Boost Converter for Nanogrid Applications," International Journal of Advanced Research in Electrical, vol. 4, no. 7, pp. 6043-6048, July 2015.

[9] S.-W. L. a. H.-L. Do, "Quadratic Boost DC-DC Converter with High Voltage Gain and Reduced Voltage Stresses,"IEEE Transactions on Power Electronics, 2018.

[10] N. A. a. E. Ozturk, "Maximum Power Point Tracking Quadratic Boost Converter for Photovoltaic Systems," in ECAI 2016 - International Conference - 8th Edition, Ploiesti, ROMÂNIA, 2016.

[11] F. M. M. D. a. N. D. Nesrine Boujelben, "Design and Comparison of Quadratic Boost and Double Cascade Boost Converters with Boost Converter," in 14th International Multi-Conference on Systems, Signals \& Devices (SSD), Sfax, Tunisia, 2017.

[12] "A New Transformerless Quadratic Boost Converter with High Voltage Gain," Javed Ahmad , Mohammad Zaid, Adil Sarwar , Mohd Tariq \& Zeeshan Sarwer, Aug 2020.

[13] N. A. b. I. S. Saban Ozdemir a, "Fuzzy logic based MPPT controller for high conversion ratio quadratic boost converter,"International Journal of Hydrogen Energy, 2017.

[14] M. A.-N. G. G. K. A. H. N. A. S. a. A. C.-P. Abdelali El Aroudi, "Analysis of Nonlinear Dynamics of a Quadratic Boost Converter Used for Maximum Power Point Tracking in a Grid-Interlinked PV System,"Energies, December 2018.

[15] D. S. a. M. Arounassalame, "High Gain Quadratic Boost Switched Capacitor Converter for Photovoltaic Applications," IEEE International Conference on Power, Control, Signals and Instrumentation Engineering (ICPCSI), pp. 1234-1239, 2017. 
[16] D. A. a. N. K. Mohanty, "Quadratic Boost Converter with integrated Energy Storage using PI controller for Low Power Photovoltaic Applications," CONTROL ENGINEERING AND APPLIED INFORMATICS (CEAI), vol. 22, no. 3, pp. 50-61, 2020.

[17] O. J. a. S. S. S. Ashish Tiwari, "Sliding Mode Controller Based Quadratic Boost Converter For Fuel Cell System," IEEE Recent Developments in Control Automation and Power Engineering (RDCAPE), pp. 142-146, 2017.

[18] K. M. K. R. M. P. P. M. R. J.S.V. Siva Kumar, "Design and simulation of High Voltage Gain current fed full-bridge voltage doubler Converter Fed Multilevel Inverter for Fuel Cell Powered Electric Vehicle,"International Journal of Emerging Trends in Engineering Research, vol. 8, no. 9, pp. 6191-6195, 2020.

[19] V. K. a. R. K. Ashok Bhupathi Kumar Mukkapati, "Genetic algorithm assisted fixed frequency sliding mode controller for quadratic boost converter in fuel cell vehicle," IET Electrical Systems in Transportation, vol. 10, no. 1, pp. 81-88, 2020.

[20] A. E. A. A. C.-P. G. G. C. O. a. L. M.-S. Reham Haroun, "Impedance Matching in Photovoltaic Systems Using Cascaded Boost Converters and Sliding-Mode Control,"IEEE TRANSACTIONS ON POWER ELECTRONICS, vol. 30, no. 6, pp. 31853199, June 2015.

[21] L. M.-S. a. G. G. Oswaldo López-Santos, "Efficiency analysis of a sliding-mode controlled quadratic boost converter," IET Power Electronics, vol. 6, no. 2, pp. 364-373, 2013.

[22] F. Wang, "A novel quadratic Boost converter with low current and voltage stress on power switch for fuel-cell system applications," Renewable Energy, 2017.

[23] N. A. H. K. a. I. S. Selami Balci, "Performance Analysis of Interleaved Quadratic Boost Converter with Coupled Inductor for Fuel Cell Applications,"IEEE, pp. 3541-3546, 2016.

[24] M. L. I. L. a. M. T. DAN LASCU, "A New Quadratic Boost Converter with PFC Applications," in 10th WSEAS International Conference on CIRCUITS, Vouliagmeni, Athens, Greece, July 2006.

[25] H. W. a. I. Batarseh, "Comparison of Basic Converter Topologies For Power Factor Correction,"IEEE, pp. 348-353, 1998.
[26] X. R. X. M. a. Z. Y. Kai Yao, "Variable-Duty-Cycle Control to Achieve High Input Power Factor for DCM Boost PFC Converter," IEEE TRANSACTIONS ON INDUSTRIAL ELECTRONICS, vol. 58, no. 5, pp. 1856-1865, May 2011.

[27] V. L. a. V. DivyaNavamani.J, "Efficiency comparison of Quadratic boost DC-DC converter in CCM and DCM," in IEEE Sponsored 2'nd International Conference On Electronics And Communication SYSTEMS(ICECS), 2015.

[28] D. a. M.Arounassalame, "Control of Quadratic boost converter using Fractional order PID controller," in IEEE, International Conference on Innovations in Power and Advanced Computing Technologies [iPACT], 2017.

[29] D. R. V. A. Viji Vijayakumar, "Sliding Mode Controlled Quadratic Boost Converter," IEEE, International Conference On Computation Of Power, Energy, Information And Communication (ICCPEIC), pp. 189-193, 2014.

[30] K. a. C. Bunlaksananusorn, "Analysis Design and Experimental Verification of a Quadratic Boost Converter," IEEE, 2014.

[31] A. a. S. P. Kumar, "Analysis and Comparison of Conventional and Interleaved DC/DC boost converter,"IEEE, 2nd International Conference on Current Trends in Engineering and Technology, ICCTET'14, pp. 198-205, July 2014.

[32] N. K. M. a. A. K. S. D. Amudhavalli, "High Power High Gain Non-Isolated Interleaved Quadratic Boost Converter with Voltage Multiplier Cell".

[33] G. K. a. M. P. Vijay Joseph Samuel, "Ultra-high gain DC-DC converter based on interleaved quadratic boost converter with ripple-free input current,"International Transactions on Electrical Energy Systems, 2020.

[34] G. K. a. M. P. Vijay Joseph Samuel, "High Gain Interleaved Quadratic Boost DC-DC Converter,"IEEE, 2nd International Conference on Power and Embedded Drive Control (ICPEDC), pp. 390-395, 2019.

[35] F. S. P. J. A. a. S. G. Garcia, "Comparison of NonInsulated, High-Gain High-Power, Step-Up DC-DC Converters," IEEE, pp. 1343-1347, 2012.

[36] T. R. C. a. S. K. M. Subhendu Bikash Santra, "Analysis and design of novel non-isolated quadratic boost DC-DC converter," Int. J. Power Electronics, vol. 11, no. 4, pp. 427-459, 2020. 
[37] R. K. S. a. R. M. Anish Ahmad, "A Novel NonIsolated Magnetically Coupled Based Bidirectional Quadratic Converter," IEEE, 2016.

[38] J.-P. G. G. C. a. M. M. Riad KADRI, "Performance Analysis of Transformless Single Switch Quadratic Boost Converter for Grid Connected Photovoltaic Systems," in International Conference on Electrical Machines - ICEM, Rome, 2010.

[39] K. V. a. R. J. J. Divya Navamani, "Non-isolated high gain DC-DC converter by quadratic boost converter and voltage multiplier cell,"Ain Shams Engineering Journal, 2016. 